\title{
Phytotoxicity and allelopathic impact of Impatiens glandulifera
}

\section{Ligita Baležentienè}

Aleksandras Stulginskis University, Studentu 11, Akademija 53361, Kaunas district, Lithuania
The knowledge of how invasive species spread in a new environment might be important for their management control. Moreover, biochemical interaction underlies the novel weapon hypothesis thus presenting one of numerous explanations for species invasiveness. This study aimed to determine the total phenolics content in various parts of I. glandulifera and evaluate their phytotoxicity on the germination of monocot and dicot species. Phytotoxicity and allelopathic activity of worldwide invasive Impatiens species (Balsaminaceae) I. glandulifera (originated in the Himalayas) on wheat and rapeseed germination and seedling growth was assessed ex situ at Aleksandras Stulginskis University in 2016. The phenolic content ranged between 0.615 and $7.566 \mathrm{mg} \mathrm{g}^{-1}$ in Impatiens extracts, however, it significantly inhibited germination and seedling growth of the recipient species. Seed germination and seedling emergence are the outcomes of a sequence of biological events initiated by water imbibition followed by enzymatic metabolism of storage nutrients. The recorded germination rate was different for each recipient species. Inhibition of Impatiens extracts was recorded stronger for rapeseed germination (11.5$81 \%)$ than that for wheat germination (71-86.5\%), possibly due to different seed coat anatomy and thus its permeability. Therefore the strongest inhibition (86.5\%) was recorded for rapeseed germination (11.5\%) in $0.2 \%$ fruit + seed extract of I. glandulifera. Mean length of wheat hypocotyl $(14.2 \mathrm{~mm})$ and radicle $(4.4 \mathrm{~mm})$ exhibited a weaker response to the extract of I. glandulifera than rapeseed ( $4.4 \mathrm{~mm}$ and $1.4 \mathrm{~mm}$, respectively). Consequently, recruitment and regeneration of native species might be negatively affected by the invasive Impatiens species in invaded habitats.

Keywords: allelopathy, germination, phenolics, seedling, Impatiens glandulifera

\section{INTRODUCTION}

The spread and recruitment of alien species in new territories over native range might be associated

* Corresponding author. Email: ligita.balezentiene@asu.lt with the traits of different species and environment conditions. Between invasion explanations, the "natural enemies hypothesis" is the primary hypothesis constructed on the absence of the natural enemies that control population growth of many exotics as community invaders relative to their 
importance in native communities (Keane, Crawley, 2002). Furthermore, many of the worldwide and ecologically devastating invaders are not as successful in their native ranges. Nonetheless, currently it is considered that the emergence of biochemical compounds of the invader has harmful effects on the species of the recipient plant community, i.e., allelopathy is observed (Inderjit et al., 2006). This nonresource mechanism would be considered a potential mechanism for explaining the significant success of some invasive species. Nevertheless, neither is allelopathy a unifying theory for plant interactions, nor do we espouse the view that allelopathy is the dominant way of plant interaction; we argue that a non-resource mechanism should be returned to the discussion table as a potential one for explaining the remarkable success of some invasive species (Iason et al., 2012). Although biochemical interactions in ecosystems were reported long ago, Fraenkel (1959) emphasised the ecological significance of secondary metabolites (Iason et al., 2012). Currently, the chemomediator role of secondary metabolites has been reported as multifunctional regulation of the structure and functions of both plants and ecosystems (Inderjit et al., 2006; Müller-Schärer et al., 2004). Numerous studies on the impact of invasive species on the neighbouring plant species suggest that invasion reduces the richness of plant species (Callaway, Ridenour, 2004). Currently, most research is directed at finding why alien invasive plant species are more successful than native plants. The success of invasive species lies in the production and release of allelopathic compounds by the invader that are harmful to plant neighbours in the introduced range. Phenolic compounds constitute a large group of secondary metabolites in plants and thus may play an important role in plant communities (Li et al., 2010). Phenolic acids are characterised by specific strong antioxidant activity. They are able to protect cell membranes, structural proteins, enzymes, membrane lipids, or nucleic acids from the oxidative damage. Significant content of phenolic acids accumulate in leaves, flowers, and roots of different Impatiens spp. (Szewczyk, Olech, 2017).
This study aimed at determining (1) the biochemical characteristics of Impatiens glandulifera which facilitate its invasion success, (2) the total phenolic content in various parts of plants, their biological activity and variability in phytotoxicity, and (3) their effect on the germination of monocot and dicot recipient species.

\section{MATERIALS AND METHODS}

A plant data set was pre-selected for screening in the central part of Lithuania, near the intensive traffic highway Via Baltica, an invasion corridor. The plant data set comprised Impatiens glandulifera (I. glandulifera) as an invasive species in the EPPO list (2006), also present in Lithuania. This species was collected for the assessment along the banks of the Nemunas and the Marvele rivers (54 $\left.54^{\prime} 12.2^{\prime \prime} \mathrm{N} 23^{\circ} 51^{\prime} 29.5^{\prime \prime} \mathrm{E}\right)$. The species is included in the Lithuanian National List of Invasive Species (Lietuvos invazinių rūšiu sąrašas, 2016). Allelopathic activity of two invasive Impatiens species (Balsaminaceae), namely, I. glandulifera (originated in the Himalayas), was assessed ex situ in 2016. I. glandulifera was intentionally introduced as ornamental plant in the late 19th century and became highly invasive in Central and Western Europe due to high germination, seedling emergence, and seedling frost resistance (Skálová et al., 2012). The spread of I. glandulifera can be attributed to autochory and accidental zoochory or anthropochory (Malíková Prach, 2010).

The germination was recorded under seed germination $>50 \%\left(\mathrm{G}_{50}\right)$ in distilled water (control). Thereafter, the $G_{50}$ rate was equated to $100 \%$. This method enables evaluating not only inhibitory, but also stimulatory effects of extracts. Winter oil rapeseed, R (Brassica napus L., Dicot) cv. Cult and spring wheat, W (Triticum aestivum L., Monocot) cv. Hamlet germinate fast, possess high germination energy, and therefore were chosen as recipient plants. One hundred seeds were placed on filter paper in a Petri dish of $6 \mathrm{~cm}$ diameter. Five $\mathrm{ml}$ aqueous Impatiens spp. extracts (concentrations 0, 0.02, 0.05, 0.1, and $0.2 \% \mathrm{w} / \mathrm{v}$ ) were put in the Petri dish of each variant per treatment. Treatments were replicated 
four times. The Petri dishes were kept at $26^{\circ} \mathrm{C}$ for $16 \mathrm{~h}$. Seeds sown in distilled water served as control. Seeds were considered germinated when the radicle emerged from the seed coat.

Secondary metabolites phenolics from plant materials were released from the matrix by means of extraction. Total phenolic content (TPC) in extract samples was determined using Singleton and Rossi (1965) colorimetric method, which relies on a colorimetric reaction and direct measurement of photo absorption in the ultraviolet region (Singleton, Rossi, 1965). In determining the TPC, the standard curve with chlorogenic acid (Sigma, Aldrich, Germany) was used. One ml of extract was mixed with $45 \mathrm{ml}$ of distilled water; $1 \mathrm{ml}$ of Folin-Ciocalteu reagent (Merck, Darmstadt, Germany) was added and mixed thoroughly. After $3 \mathrm{~min}, 3 \mathrm{ml}$ of $\mathrm{Na}_{2} \mathrm{CO}_{3}$ was added, then the mixture was allowed to stand for $2 \mathrm{~h}$. The absorbance was measured at $760 \mathrm{~nm}$. Samples were analysed in two replications. Identification and quantification of individual target polyphenolic compounds was carried out by UV-Vis spectrophotometry (Bechman DU-40, Germany). To evaluate the effects of selected chemicals, a standard equivalent of the total phenolic content in Impatiens spp. was estimated via the standard curve of chlorogenic acid. The equivalent value was calculated by multiplying the absorbance of each sample by a single value of equivalent chemical weight per absorbance unit determined under the same condition. In crude extracts of each fraction, TPC of Impatiens spp. was expressed as a fresh weight basis in mg per $\mathrm{g}$ chlorogenic acid equivalent (CAE).

\section{Statistical analysis}

Significant differences among the means were determined using Kruskal-Wallis test, KW-H, and F-test (ANOVA). Correlation coefficient $r$ between the parameters of extracts and seedlings was calculated in order to evaluate their interaction. the results of allelopathic effects were statistically evaluated by using the statistical package STATISTICA v.7 (StatSoft Inc., 2004). The results regarding the concentration of phenols, germination, and seedling parameters are presented as mean $\pm \mathrm{SD}$ of four independent analyses at the $p<0.05$ significance level.

\section{RESULTS AND DISCUSSION}

Total phenolic content $\left(0.585-7.566 \mathrm{mg} \mathrm{g}^{-1}\right)$ was recorded in the assessed extracts, which was also significantly subjected to concentration $(r=0.9, p=0.000)$ and insignificantly to the part of the plant $(r=0.2, p>0.1)$ (Figs. 1, 2). The recorded relatively low TPC might be related to favourable conditions due to a lack of pests in the invaded habitats, since these secondary metabolites are generally produced as a response to environmental factors (light, temperature, and pollution) or plant damages (Callaway, Ridenour, 2004). Significantly, the highest $\left(7.566 \mathrm{mg} \mathrm{g}^{-1}\right)$ and the lowest TPC $\left(0.585 \mathrm{mg} \mathrm{g}^{-1}\right)$ were recorded in $0.2 \%$ blossom and $0.02 \%$ fruit+seed extracts, respectively.

Concomitant with former researchers (Iason et al., 2012; Hanley, Whiting, 2005), phenolics stimulated the phytotoxicity of I. glandulifera and inhibited the germination of both recipient species (Fig. 1, 2). A strong correlation between TPC and recipients germination $\left(r_{\text {rapeseed }}=-0.7\right.$ and $\left.r_{\text {wheat }}=-0.7, p=0.000\right)$ confirmed significant phytotoxicity of I. glandulifera extracts.

However, germination inhibition was different in each tested recipient, possibly due to their different structure of the seed coat (testa) (Moise et al., 2005). As a result, seed germination and seedling emergence exhibited the outcomes of a sequence of biological events initiated by water imbibition followed by enzymatic metabolism of storage nutrients. The recorded inhibition by extracts was stronger for rapeseed germination than for wheat germination, possibly due to different seed coat anatomy and thus its permeability. The thick, lignified coats of wheat grain were almost impermeable to extracts, thereby maintaining their ability to reduce the phenol inflow to the embryo. Consequently, wheat grains were specific with higher mean germination $(78.1 \%)$ than rapeseed $(55.1 \%)$ in extracts. I. glandulifera inhibited rapeseed (mean by $42.9 \%$ ) stronger than wheat 

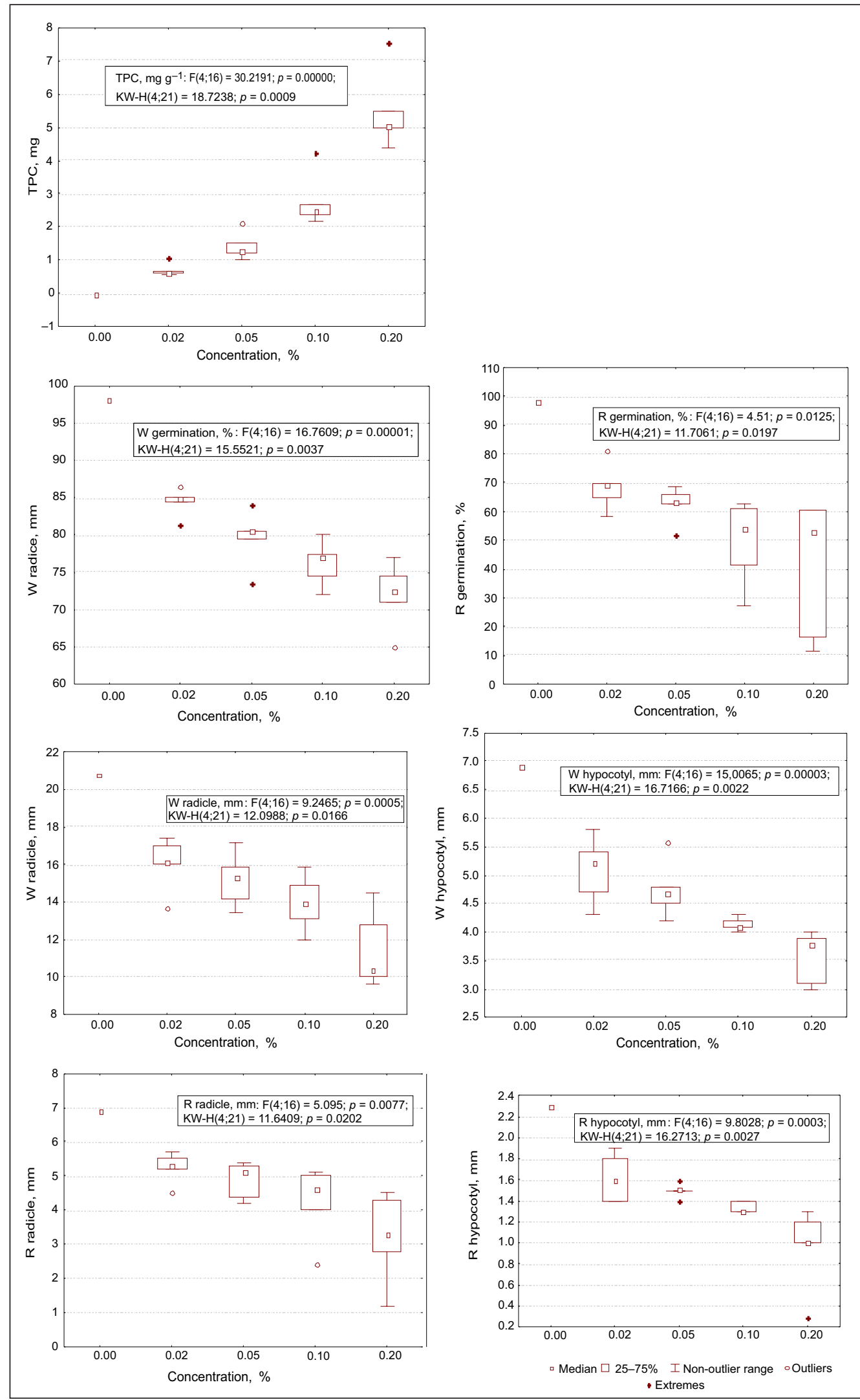

Fig. 1. Distribution of TPC and seedling parameters in extracts of different concentration. Significant differences among the means were determined using Kruskal-Wallis test, KW$\mathrm{H}$, and $\mathrm{F}$ - test. $\mathrm{R}$ - rapeseed, $\mathrm{W}$ - wheat 


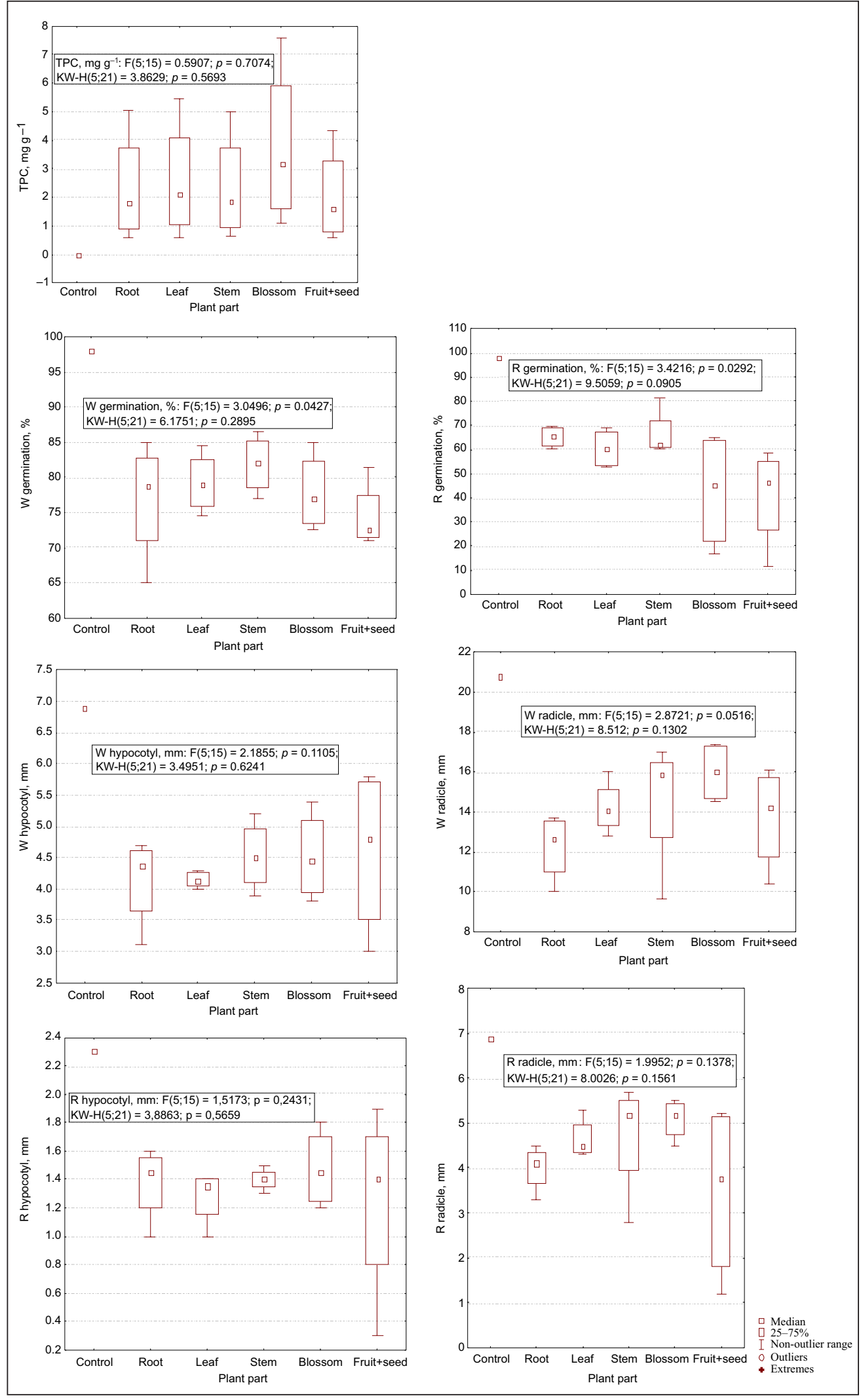

Fig. 2. Distribution of TPC and seedling parameters in extracts of different parts of plant. Significant differences among the means were determined using Kruskal-Wallis test, KW$\mathrm{H}$, and $\mathrm{F}$ - test. $\mathrm{R}$ - rapeseed, $\mathrm{W}$ - wheat 
germination (mean by 19.9\%) due to a different structure of their seed coats.

Mean length of wheat and rapeseed radicles ranged between 14.2 and $4.4 \mathrm{~mm}$, and hypocotyls between 4.4 and $1.4 \mathrm{~mm}$, respectively (Figs. 1,2). The highest suppression was observed on length of hypocotyls of both recipients than on the radicles in $0.2 \%$ extracts. Seedling analysis revealed that their parameters correlated significantly strongly with extract concentration $(r=-0.8$, $p=0.00)$ and insignificantly with the donor part $(r=-(0-0.2), p>0.1)$ due to different TPC.

\section{CONCLUSIONS}

The present allelopathic research aimed to determine the allelochemical activity as a potential ecological factor driving plant invasions. The findings revealed that invasive species contained phenolics that were phytotoxic to the germination of the recipient and suppressed seedling growth. Consequently, phytotxicity of I. gladulifera may inhibit the germination and regeneration or recruitment of the neighbouring species in invaded habitats. Thus, Impatiens glandulifera may considerably reduce the species diversity or locally out-compete the native plants in invaded habitats. The revealed allelochemical phytotoxicity of Impatiens glandulifera should be considered as a partial explanation of its high aggressiveness and thus may help improve our knowledge of species invasiveness.

\section{ACKNOWLEDGEMENTS}

The author would like to thank the Institute of Ecology and Environment for the lab space, technical support, and assistance.

Received 13 February 2018

Accepted 18 May 2018

\section{References}

1. Callaway RM, Ridenour WM. Novel weapons: a biochemically based hypothesis for invasive success and the evolution of increased competitive ability. Front Ecol Environ. 2004; 2: 436-3.

2. Hanley M, Whiting M. Insecticides and arable weeds: effects on germination and seedling growth. Ecotoxicity. 2005; 14: 483-490.

3. Iason GR, Dicke M, Hartley SE. The ecology of plant secondary metabolities. From genes to global process. Cambridge: Cambridge University Press; 2012. 335 p.

4. Inderjit, Callaway RM, Vivanco JM. Can plant biochemistry contribute to understanding of invasion ecology? Trends Plant Sci. 2006; 11: 574-80.

5. Keane RM, Crawley MJ. Exotic plant invasions and the enemy release hypothesis. Trends Ecol Evolut. 2002; 17: 164-70.

6. Kowarik I. Biologische Invasionen - Neophyten und Neozoen in Mitteleuropa. Stuttgart: Verlag Eugen Ulmer GmbH \& Co. 2003. $215 \mathrm{p}$.

7. Li ZCh, Wang Q, Ruan X, Pan CD, Jiang DA. Phenolics and plant allelopathy. Molecules. 2010; 15: 8933-52.

8. Lietuvos invazinių rūšių sąrašas [List of invasive species in Lithuania]. LR AM D1726/2012-09-10.Vilnius. 2016. Lithuanian.

9. Galvonaitė A, Misiūnienė M, Valiukas D, Buitkuvienė MS, editors. Lietuvos klimatas [Lithuanian climate]. Vilnius: Lietuvos hidrometeorologijos tarnyba; 2007. 180 p. Lithuanian.

10. Malíková L, Prach K. Spread of alien Impatiens glandulifera along rivers invaded at different times. Ecohydrology and Hydrobiology. 2010; 10: $81-5$.

11. Moise JA, Han S, Gudynaite-Savitch L, Johnson DA, Miki, BLA. Seed coats: structure, development, composition and biotechnology. In vitro cellular deviation biology. Planta. 2005; 41: 620-44.

12. Müller-Schärer $H$, Schaffner $U$, Steinger $T$. Evolution in invasive plants: implications for biological control. Trends Ecol Evolut. 2004; 19: 417-22. 
13. Szewczyk K, Olech M. Optimization of extraction method for LC-MS based determination of phenolic acid profiles in different Impatiens species. Phytochem Lett. 2017; 20: 322-30.

14. Singleton VL, Rossi JA Jr. Colorimetry of total phenolics with phosphomolybdic-phosphotungstic acid reagents. Am J Enology Vitic. 1965; 16: 144-58.

15. Skálová H, Moravcová L, Pyšek P. Germination dynamics and seedling frost resistance of invasive and native Impatiens species reflect local climatic conditions. Perspect Plant Ecol Syst. 2011; 13: 173-80.

\section{Ligita Baležentienè}

\section{IMPATIENS GLANDULIFERA FITOTOKSIŠ- KUMAS IR ALELOPATINIS POVEIKIS}

\section{Santrauka}

Žinios apie invazinių rūšių plitimą naujoje aplinkoje gali būti svarbios jų kontrolès vykdymui. Be to, biocheminè sąveika yra viena iš daugelio „naujo ginklo“ hipotezių, aiškinančių rūšių invazyvumą. Šiuo tyrimu siekta nustatyti bendrą fenolinių junginių kiekị ịvairiose I. glandulifera dalyse ir ịvertinti jų fitotoksiškumą vienskilčių ir dviskilčių rūšių daigumui. Invazinès Impatiens rūšies (Balsaminaceae) I. glandulifera (kilusios iš Himalajų) fitotoksiškumas ir alelopatinis aktyvumas kviečių ir rapsų daigumui ir daigu augimui buvo tirtas ex situ Aleksandro Stulginskio universitete 2016 metais. Fenolių kiekis I. glandulifera ekstraktuose svyravo tarp 0,615 ir $7,566 \mathrm{mg} \mathrm{g}^{-1}$, tačiau reikšmingai slopino recipientų rūšių daigumą ir daigų augimą. Sèklų daigumas ir daigų pasirodymas yra biologinių procesų rezultatas, inicijuotas vandens brinkimo, kuris paskatina atsarginių maisto medžiagų fermentinį metabolizmą. Kiekviena recipiento rūšis pasižymèjo skirtingu daigumu. Nustatytas stipresnis Impatiens ekstraktų slopinamasis poveikis rapsų daigumui (11,5-81\%) nei kviečių (71-86,5\%), ir tam ịtakos galejjo turèti skirtingą pralaidumą lemianti sèklų luobelès anatomija. Rapsų daigumas (11,5\%) stipriausiai buvo slopintas $(86,5 \%)$ 0,2 \% I. glandulifera vaisių + sèklų ekstrakte. Vidutinis kviečių hipokotilio (14,2 $\mathrm{mm})$ ir gemalinès šaknelès $(4,4 \mathrm{~mm})$ ilgis silpniau reagavo ì I. glandulifera ekstraktus nei rapsų (atitinkamai 4,4 $\mathrm{mm}$ ir 1,4 mm). Todèl vietinių rūšių ìsikūrimas ir atsikūrimas gali būti probleminis invazinès Impatiens rūšies paveiktuose arealuose.

Raktažodžiai: alelopatija, daigumas, fenoliai, daigai, Impatiens glandulifera 